Пічугіна Ю. В., к.е.н., доцент Залецька І. О., старший викладач Максимова Ю. О., викладач Одеський національний університет імені I. I. Мечникова м. Одеса, Украӥна

DOI: https://doi.org/10.30525/978-9934-26-036-0-6

\title{
ОСОБЛИВОСТІ ФУНКЦІОНУВАННЯ ВІРТУАЛЬНОЇ ЕКОНОМІКИ ЯК ВЕКТОРА РОЗВИТКУ СУЧАСНОГО СУСПІЛЬСТВА
}

Виникнення i розвиток віртуальної економіки пов'язані 3 появою нових інформаційно-комунікаційних технологій у всіх сферах сучасної економіки. Така система дозволяє працювати 3 великими масивами інформації в онлайн режимі, значно підвищувати продуктивність праці, а також робити життя людей комфортнішим, змістовим і цікавим. Розвиток інформаційних технологій є основним напрямком розвитку цифрової та реальної економіки.

Можна відзначити, що глобалізація змінила уявлення про економіку докорінно. Громадська еволюція потягнула за собою довгий ланцюг модифікацій, які стали причинами для появи віртуальної економіки. Відомий фахівець в області вивчення віртуальної економіки Едвард Кастранов називає віртуальну економіку «унікальною економічною системою зі своїми 
виробництвами, активами і взаємовідносинами 3 реальною економікою» [1, с. 57].

У зв'язку 3 частим використанням терміна «віртуальна економіка» необхідно визначити сутність, особливості функціонування та відмінності їі від традиційної економіки.

Виділяють такі форми прояву віртуальної економіки:

- інформаційно-інтелектуальна економіка, що характеризується появою складної форми капіталу, розвиток якої має необмежений ресурс за якісно-кількісними параметрами;

- фінансова економіка 3 домінуючим впливом фінансового капіталу;

- глобальна економіка - єдиний універсальний механізм управління світовими господарськими зв'язками [2].

Головною причиною переходу до нової, віртуальної економіки стала науково-технічна революція другої половини XX ст., яка якісно змінила продуктивні сили, кардинально змінивши матеріально-технічну базу виробництва. Все це дозволило скоротити час обробки і передачі інформації у будь-який куточок планети, а також значно прискорити процеси розвитку економіки і ще більш посилити роль людського фактора.

Слід зазначити, що незважаючи на те, що віртуальна економіка є ринковою, і їй притаманні всі характерні для ринку риси, вона має відмінності від традиційної економіки. Балабанов I.T. визначив у порівнянні реальної та віртуальної економіки по чотири основні аспекти:

1. За просторовою ознакою віртуальна економіка від звичайної відрізняється тим, що просторової одиницею замість господарства району, області, країни виступає господарство всієї земної кулі.

2. Структурні відміни віртуальної економіки полягають у тому, що замість складової у вигляді галузі економіки окремої країни, з'являються складові у вигляді світового господарського комплексу під керівництвом холдингових компаній i транснаціональних корпорацій. 
3. Ресурсний перелік значно збільшується у віртуальної економіці за рахунок таких товарів, як електронні книги, комп'ютерні ігри, рекламні тексти і т.Д. Домінуючу роль відіграють товари у вигляді автоматизованих інформаційних технологій.

4. Технологічною перевагою віртуальної економіки стає те, що рекламні функції забезпечуються в мережі Інтернет, використовуючи мобільний зв’язок. При цьому мережа електронних магазинів, призводить до появи нового поняття - електронна торгівля [4].

Ці особливості віртуальної економіки забезпечують потенціал для підвищення продуктивності будь-якого виду діяльності.

Уважно слід вивчити негативні аспекти віртуальної економіки, де з'являється ряд процесів, які складно піддаються контролю i негативно позначаються на різних сторонах економічного та соціального життя суспільства. До цих процесів можна віднести:

1. Наявність певних форм руху капіталу, що дозволяють створювати гігантські фінансові піраміди.

2. Поява можливості практично миттєво виробляти спекулятивні угоди $з$ товарами, грошима, цінними паперами.

3. Наявність асиметричності ринку - продавець знає про товар значно більше, ніж покупець, але при цьому пропозиція значно перевищує попит.

4. Для досягнення симетричності віртуального ринку необхідно забезпечити наявність додаткових джерел інформації про товари і продавців; ефективну роботу системи поручительства і гарантій і т.д.

5. Підвищена ступінь конкуренції між суб'єктами віртуального ринку.

6. Невисокий рівень безпеки електронних операцій, що несе 3 собою нові широкі можливості всякого роду шахрайства і зовсім не характерні для реальної економіки ризики.

7. Процес купівлі-продажу відбувається на основі віртуального вивчення товару, що може значно різнитися з його реальним чином. 
8. Ризик продавця полягає в тому, що товар може бути не оплачений покупцем або буде повернено продавцю.

Проведений аналіз дозволяє виділити наступні відмінні риси віртуальної економіки:

- залучення в економічні відносини більшої кількості учасників (можливо з підвищенням середнього рівня комп'ютерної освіченості цих учасників);

- збільшення взаємопов'язаності цих учасників (виникнення залежності «кожного від всіх і всіх від всього»);

- збільшення швидкості всіх операцій, що дозволяє економити тимчасові витрати; поява безмежності можливостей (як продавців, так і покупців, іноді 3 непередбачуваними наслідками);

- підвищення механізмів впливу криптовалюта на монетарну політику центральних банків [3].

Можна зробити висновок, що реальна економіка спирається головним чином на наявні в дійсності відносини. Віртуальна економіка вміщує в себе дві сторони життя: реальну і віртуальну, тобто за допомогою інформаційних та комунікаційних засобів можуть виникати дійсні економічні відносини між реальними продавцями і покупцями.

Незважаючи на деяке негативний вплив віртуальної економіки на суспільство, вона стає об’єктивною необхідністю для сучасного світу. Є необхідність більш ефективно використовувати ¥ї переваги, так як віртуальна економіка весь час розширює зону свого впливу.

\section{Література:}

1. Балабанов И.Т. Электронная коммерция. СПб : Питер, 2001. 332 с.

2. Маслова А.В. Основные направления и формы виртуализации экономических отношений. Век качества. 2010. № 1. С. 12-13.

3. Подчасова П.Т. Віртуальні підприємства як сучасна форма організації виробництва Збірник наукових пращь МННЦ ІТІС. 2009. Вип. 14. С. 24-45.

4. Тимашова Л.А. Интеллектуальная система поиска партнеров виртуальных предприятий. Управляющие системы и машины. 2006. № 1. С. 52-68. 